NBER WORKING PAPER SERIES

\title{
THE DETERMINANTS OF THE GLOBAL DIGITAL DIVIDE: A CROSS-COUNTRY ANALYSIS OF COMPUTER AND INTERNET PENETRATION
}

\author{
Menzie D. Chinn \\ Robert W. Fairlie \\ Working Paper 10686 \\ http://www.nber.org/papers/w10686
NATIONAL BUREAU OF ECONOMIC RESEARCH 1050 Massachusetts Avenue
Cambridge, MA 02138

August 2004

We thank seminar participants at Yale University and Joe Altonji, Eileen Brooks, Don Kettl, and Valery Lazarev for helpful comments and suggestions. Fairlie was partially funded by the William T. Grant Foundation. The views contained herein are solely those of the authors, and do not necessarily represent those of the institutions with which the authors are associated. The views expressed herein are those of the author(s) and not necessarily those of the National Bureau of Economic Research.

(C2004 by Menzie D. Chinn and Robert W. Fairlie. All rights reserved. Short sections of text, not to exceed two paragraphs, may be quoted without explicit permission provided that full credit, including $(\mathrm{C}$ notice, is given to the source. 
The Determinants of the global Digital Divide: A Cross-Country Analysis of Computer and Internet Penetration

Menzie D. Chinn and Robert W. Fairlie

NBER Working Paper No. 10686

August 2004

JEL No. O30, L96

\begin{abstract}
$\underline{\text { ABSTRACT }}$
To identify the determinants of cross-country disparities in personal computer and Internet penetration, we examine a panel of 161 countries over the 1999-2001 period. Our candidate variables include economic variables (income per capita, years of schooling, illiteracy, trade openness), demographic variables (youth and aged dependency ratios, urbanization rate), infrastructure indicators (telephone density, electricity consumption), telecommunications pricing measures, and regulatory quality. With the exception of trade openness and the telecom pricing measures, these variables enter in as statistically significant in most specifications for computer use. A similar pattern holds true for Internet use, except that telephone density and aged dependency matter less. The global digital divide is mainly - but by no means entirely - accounted for by income differentials. For computers, telephone density and regulatory quality are of second and third importance, while for the Internet, this ordering is reversed. The region-specific explanations for large disparities in computer and Internet penetration are generally very similar. Our results suggest that public investment in human capital, telecommunications infrastructure, and the regulatory infrastructure can mitigate the gap in PC and Internet use.
\end{abstract}

Menzie D. Chinn

LaFollette School of Public Affairs and

Department of Economics

University of Wisconsin

1180 Observatory Drive

Madison, WI 53706-1393

and NBER

mchinn@lafolette.wisc.edu

Robert Fairlie

Department of Economics

University of California

Santa Cruz, CA 95064

rfairlie@ucsc.edu 


\section{Introduction}

The study of how new technologies have diffused throughout the economy has been, and remains, a field of intense activity. Recent events, including the acceleration of productivity growth in the United States since 1995, have only served to heighten interest in this area since the acceleration appears to be connected with greater investment in information and communication technologies (ICTs). The consensus view is that the acceleration in productivity growth has been manifest at both the country and firm level of analysis (Jorgenson, 2001). Admittedly, some debate remains over the exact origins of the improved performance. While several studies have cast a skeptical eye upon the ICT-productivity story (DiNardo and Pischke, 1997; Gordon, 2000), the preponderance of the literature attributes the improvement to the introduction of new technologies (Autor, et al., 1998; Brynjolfsson and Hitt, 2003; Council of Economic Advisers, 2001).

Interest in the global diffusion of technology has also been spurred by arguments that it may increase knowledge diffusion through improving communication efficiency (e.g. Jovanovic and Rob, 1989), improve political engagement (Norris, 2001), and allow developing countries to "leapfrog" traditional methods of increasing productivity (Steinmueller, 2003). In this light, the striking international differences in information and communication technology (ICT) diffusion that exist today, often referred to as the "Global Digital Divide," may pose a serious challenge to policymakers. Many developing countries have computer and Internet penetration rates that are $1 / 100^{\text {th }}$ of the rates found in North America and Europe. For example, there are less than 6 personal computers per 1000 people in India, whereas more than 6 out of 10 people in the United States own a computer (ITU 2003).

Although these differences in technology diffusion may have substantial economic consequences, the empirical literature aimed at identifying the causes is limited. A few factors have been identified as being important, such as differentials in income, human capital, regulatory effectiveness, and telecommunications infrastructure (see Dasgupta, et al., 2001, and Wallsten, 2003 for example), but a definitive study is lacking. We remedy this deficiency in the literature with a comprehensive econometric analysis of the determinants of computer and Internet use that spans both developed and developing countries and includes a wide-range of economic, demographic and policy factors. Most previous studies have been limited in scope, either adopting a regional focus, or considering only a small set of variables. 
Our paper also provides the following innovation: in addition to isolating the empirical determinants of computer and Internet use, we undertake a systematic analysis of the relative importance of different factors in contributing to the global digital divide. Borrowing from a technique commonly used to decompose earnings gaps between groups (Blinder, 1993 and Oaxaca, 1993), we estimate separate contributions from regional differences in income, human capital, telecommunications infrastructure, and other factors.

The contribution results will allow us to directly address several issues that have been discussed in the literature. One key question is the relative importance of income in explaining the international digital divide. Many studies find a strong positive relationship between technology use and income across countries and within countries (see Quibria, et al. 2002, OECD 2001, and U.S. Department of Commerce 2002 for example), while some point to other factors -- such as telecommunications access and pricing -- as being of major importance (Dasgupta, et al. 2001 and Mann et al. 2000).

Another set of questions are prompted by findings in the recent growth literature that highlight the roles of human capital and institutional factors. The channels through which these factors affect growth are difficult to discern, but it is likely that both exert at least some influence on the rate at which new technologies are adopted. ${ }^{1}$ Hence, the first question is how important is human capital for creating demand for information and communication technology services? Computers may require substantial levels of education for use, but telephones and the Internet may require very little, according to Dasgupta, et al. (2001). Another question pertains to the impact of institutional regimes. Do factors such as legal protections and regulatory quality matter even after accounting for income? Wallsten (2003), among others, has focused on this issue.

To anticipate our results, we find that while income per capita is important in explaining the digital divide, so too are factors such as the communication infrastructure (as measured by telephone mainlines density), access to electricity, the institutional environment in the form of regulatory efficacy and the protection of property rights, and demographic characteristics. These findings inform our conclusions regarding the first two hypotheses: the income per capita differential accounts for the single most important component of the digital divide, but it is not by any means the only component. Differences in the telecommunications infrastructure are also

\footnotetext{
${ }^{1}$ The literature ascribing a role to human capital is too voluminous to cite; the canonical references include Barro (1991), whereas a recent survey is Temple (2001). For institutional factors, see Hall and Jones (1999), Acemoglu, et
} 
important, but are not terribly important for the Internet digital divide - rather it is more critical to the computer divide.

Additional results include a negative impact of urbanization on Internet use, and perhaps most interestingly, a large (positive) impact of regulatory quality or property rights on the Internet digital divide. The latter suggests that the diffusion of the Internet may be particularly dependent upon the quality of institutions prevailing in an economy. Finally, the results for demographic controls suggest that the global digital divide would be even larger if developing countries had an age composition that was more similar to the United States.

\section{Surveying the Literature}

To our knowledge, there are no systematic cross-country econometric analyses of the determinants of PC and Internet use, spanning both developed and developing countries, and a period including the last few years. Many of the extant studies have a regional focus, especially when assessing the spread of Internet use.

One of the most extensive cross-country studies of personal computer adoption is by Caselli and Coleman (2001). They examine a dataset encompassing up to 89 countries over the years 1970-90, focusing on the computer imports/worker ratio, as a proxy measure for the investment in ICT. In attempting to explain the variation in this variable, they rely upon a large set of variables, including income per worker, investment per worker, structural descriptors (the sectoral shares of agriculture and manufacturing), human capital, imports and exports from and to the OECD. They also include an institutional variable, in this case an index of property rights. Openness to imports from OECD countries, the level of educational attainment, and the index of property rights are three notable variables than enter with statistical significance.

Pohjola (2003) studies observed investment in information and communication technology in 49 countries over a more recent period, 1993-2000. He regresses ICT investment per capita on income per capita, the relative price of ICT equipment, human capital measures, the share of agriculture and openness to international trade. In addition to finding the typically high elasticity of ICT investment with respect to income (around unity), he also detects a major role for human capital and a negative impact of agriculture’s importance in the economy. ${ }^{2}$

al. (2001), and Rodrik et al. (2002).

${ }^{2}$ Unlike other cross country studies, a price variable is included, and enters into the regressions with statistical 
As a more recent technological innovation, there are far fewer examples of cross-country analyses of the determinants of Internet use. One cross-country study was conducted by Dasgupta, et al. (2001). They examine Internet use in a sample of 44 countries, spanning both OECD and developing countries, from 1990 to 1997. Their variable of focus is the Internet to telephone mainlines ratio as a dependent variable. The growth rate in this variable over the sample period is related to initial (1990) values of the Internet to telephone mainlines ratio, the urban population, income per capita, and an index of competition policy, as well as some regional dummies. The results - including a negative impact of income per capita - are somewhat difficult to interpret for a number of reasons. First, the sample period is quite early 1990-1997. Even at the end of the sample, many countries still had very low levels of Internet penetration, so the lessons that one can draw from the analysis are tentative. Second, the inclusion of regional dummies complicates the interpretation of the income variable coefficient. ${ }^{3}$

Kiiski and Pohjola (2001) examine a more recent sample, 1995-2000, and use a more conventional measure of the Internet - namely Internet hosts per 1000 inhabitants. In a broad sample encompassing about sixty OECD and developing countries, the five year growth in this variable is related to income per capita, telephone access costs, and the average years of schooling. More recently, focus has switched to policy related variables. Most recently, Wallsten (2003) examines a developing country sample of 45 countries in 2001. He relates Internet users and Internet hosts to the standard variables as well as measures of regulatory regime characteristics, including agency independence, transparency, and discretion. Price regulation is also examined. One problem in interpretation arises from the use of PCs per capita variable as a control variable. The inclusion of this variable raises the possibility of simultaneity bias, among other things.

One interesting study with a regional focus is APEC (2002). ${ }^{4}$ The 21 economies of APEC span a wider set of income per capita than those found in other studies, and hence may be

significance. However, since the price variable is the same for all countries in the panel (the US deflator for computer purchases), it is unclear what interpretation to attribute to this result. The price index is highly trended (downward) so the inclusion of the price index probably mimics that of a time trend.

${ }^{3}$ In addition, the dependent variable is somewhat unconventional: internet subscribers expressed as a ratio to telephone mainlines. This implies a long run unitary elasticity of subscribers to phone lines.

${ }^{4}$ There are a number of additional studies that have a distinctly regional focus. See Estache, et al. (2002), who focus on Latin America. Mann and Rosen (2001) examine the Asia-Pacific economies, while Oyelaran and Oyeyinka (2003) study the African experience. 
more informative than more regionally focused studies. ${ }^{5}$ APEC (2002) finds the user access cost (the cost of a 3 minute local call), political freedom, income per capita in 1995 US dollars, an urban population proportion, adult literacy rate, and the share of service valued added in GDP as statistically important determinants. Access charges and the lack of political freedom are negatively associated with Internet penetration, while income per capita, the urban ratio, literacy, and a large service sector share are all positively associated. ${ }^{6}$

In a related line of research, a few recent studies have explored the determinants of the digital divide between demographic groups within countries. Using microdata from the U.S. Current Population Survey, a few recent studies have explored the causes of the digital divide across racial groups (U.S. Department of Commerce 2000, Fairlie 2003, and Novak and Hoffman 1998). Racial disparities in access to computers and the Internet appear to be primarily, but not entirely, due to disparities in income and education, and language barriers. Research using microdata from other countries suggests that income and education are important determinants of computer ownership and Internet use, and thus may contribute to digital divides within those countries (see for example, OECD 2001 for several countries, Primrose (2003) for Australia, Singh (2004) for Canada, and Ono and Zavodny 2003 for Japan).

Note that in none of the previous studies has there been a quantification of the relative importance of different factors in explaining the digital divide. That is, while there are a number of studies that relate per capita computer stock and Internet penetration to purported determinants, or discuss the statistical significance of the estimated coefficients, none of them decomposes the gaps between, say, the United States and Africa, into portions attributable to regulatory differences, or to telephone density.

\section{Data}

Data on technology use and telecommunications are from the International Telecommunications Union’s (ITU) World Telecommunication Indicators Database. The data are obtained primarily through annual questionnaires administered by the Telecommunications Development Bureau (BDT) of the ITU. Supplemental information is obtained from reports

\footnotetext{
${ }^{5}$ The United States has the highest income per capita in the grouping, at \$31,600 in 2001, while Papua New Guinea has the lowest at \$897; the economies are located in both of the Americas, Asia, and Oceania.

${ }^{6}$ The supporting study by Liu and San (undated) reports similar results for a broader sample, using a Gompertz specification of technology diffusion.
} 
from telecommunication ministries, regulators, operators, and ITU staff. Detailed data are available on telephone, personal computer, Internet, and other telecommunications and electronics use. The ITU data also contain detailed information on telephone costs.

Computer and Internet penetration rates analyzed below are derived from the number of personal computers and Internet users per 100 people. These measures of technology use from the ITU are the only ones available for a large number of countries over the past several years. However, they may suffer from two notable limitations. First, the number of personal computers may understate the total use of computers in some countries in which mainframe computers are prevalent (World Bank 2002). This is probably less of a concern, however, focusing on more recent data with the rise of networked PCs. Second, the number of Internet users is based on reported estimates of users, derivations from reported Internet Access Provider (ISP) subscriber counts, or calculated by multiplying the number of Internet hosts by an estimated multiplier. Thus, Internet use may be understated, particularly in developing countries where many commercial subscribers rent computers connected to the Internet (World Bank 2002). ${ }^{7}$

The primary source for data on demographics, income, and other variables included in the regression analysis is the World Bank's World Development Indicators database. We also use indices of rule of law and regulatory quality drawn from the World Bank's Governance Indicators database. The construction and attributes of these indicators are described in much greater detail in Kaufmann, Kraay and Mastrizzi (2003). Our primary measure of human capital, average years of schooling, is derived from the World Bank’s Edstats. More details on all variables included in the analysis are provided in the Appendix.

\section{Cross-Country Differences in Computer and Internet Penetration Rates}

Computer and Internet use has grown rapidly over the past decade. As reported in Figure 1, there were only 2.5 personal computers per 100 people in the world in 1990. By 2001, the number of computers per 100 people had climbed to nearly 9. Internet use grew from essentially zero in the early 1990s to 8.1 percent of the world's population by 2001.

\footnotetext{
${ }^{7}$ Estimates of the number of Internet hosts in a country may also have measurement problems because they are based on country codes and do not necessarily capture the physical location of the host. Furthermore, hosts that do not have a country code are assigned to the United States (Wallsten 2003).
} 
The relatively high current rates of use, however, mask large disparities across regions of the world. ${ }^{8}$ Figure 2 reports computer penetration rates by region in $2001 .^{9}$ In North America, there are 61.1 computers per 100 people, whereas there are only 0.5 computers per 100 people in South Asia. Computer penetration rates in Sub-Saharan Africa are also strikingly low with only 1.0 personal computers per 100 people. Other regions have higher penetration rates, but none of these is as large as one-third the North American rate. Even in Europe and Central Asia, there exist only 18.1 personal computers per 100 people.

A comparison of Internet penetration rates reveals similar regional patterns (Figure 3). In North America, roughly one half of the population uses the Internet. In contrast, slightly more than one half of one percent of the population uses the Internet in South Asia and Sub-Saharan Africa. Internet use is higher in Europe and Central Asia with 16.5 users per 100 people, but very low in other regions of the world. Internet penetration rates in East Asia and the Pacific, Latin America and the Caribbean, and The Middle East and Africa are only 6.9, 5.0 and 2.4 per 100 people, respectively.

Examining computer and Internet penetration rates across countries also reveals interesting patterns. Table 1 reports countries with the highest and lowest computer penetration rates. ${ }^{10}$ The United States has the highest computer penetration rate. Perhaps not surprisingly, the top ten also contains many European countries (Sweden, Denmark, Switzerland, Norway and the Netherlands) and Canada. Australia, Singapore and Korea also have high computer penetration rates. All of these countries are relatively wealthy with the exception of Korea.

The bottom of the distribution is mainly comprised of very poor countries in Sub-Saharan Africa. All of the reported countries have computer penetration rates of less than 2 users per 1000 people. The computer penetration rate in the United States, for example, is nearly 550 times larger than the penetration rate in Ethiopia. Two countries located in East Asia and the Pacific, Cambodia and Myanmar, also have extremely low computer penetration rates. In

\footnotetext{
${ }^{8}$ Fink and Kenny (2003) note that growth rates in Internet use per capita have been higher in poor countries than those in wealthy countries, and thus the digital divide is shrinking. Given the large differences that exist today, it may be a considerable amount of time before we witness convergence in Internet use. They also point out that the digital divide is not apparent when Internet use is normalized by GDP rather than population. We retain our focus, however, on the conventional per capita measures of ICT use, and identify how much of the gap is explained by income differences in a multivariate analysis.

${ }^{9}$ Regional definitions are from the World Bank.

${ }^{10}$ We do not report estimates for countries with populations under 1 million.
} 
Cambodia, there are only 0.15 computers per 100 people and in Myanmar there are only 0.11 computers per 100 people.

Table 1 also reports estimates of computer penetration for the largest countries in the world. Japan has a relatively high computer penetration rate, whereas the other largest countries in the world have relatively low computer penetration rates. In China, there are less than 2 personal computers per 100 people. The computer penetration rate is even lower in India. There are only 0.58 computers per 100 people.

Internet penetration rates generally follow the same patterns across countries as computer penetration rates. As expected, the ranking of countries by computer penetration rates is roughly similar to the ranking of countries by Internet penetration rates. ${ }^{11}$ Some interesting changes, however, occur at the top of the distribution. Most notably, Korea and Sweden have Internet penetration rates that are slightly higher than the U.S. rate. Also, New Zealand (46.1) and Finland (43.0) enter the list of top 10 countries displacing Switzerland and Australia. There is more movement into and out of the bottom ten list, but all of these countries have both computer and Internet penetration rates well below 1 per 100 people.

\section{The Determinants of Computer and Internet Use}

\subsection{Empirical Model of Computer Use}

The basic framework for analyzing the use of personal computers and the Internet is simply a demand and supply one. Demand is driven by consumers and firms, whereas supply is driven by a few countries that export the bulk of equipment (for computer use) and many firms in all countries (for Internet providers). In the case of computers, they represent a derived demand, insofar as firms are concerned; and a final demand for consumers. For firms, the marginal product of ICT equipment is a function of the demand for the final good produced, which will be correlated with income per capita. The "after-tax" price of goods sold will also depend upon how burdened firms are by regulations; inefficiently implemented regulations, or regimes where expropriation is the norm, will reduce the expected return to investing in capital of all sorts, and hence reduce the derived demand for ICT equipment.

The productivity of ICT equipment depends upon the attributes of the labor stock if labor and ICT equipment are complements. Hence, the stock of human capital, measured by either

\footnotetext{
${ }^{11}$ Only 24.2 percent of all countries had rankings that were more than 10 places apart.
} 
years of schooling, or the illiteracy rate, should be important. Another complementary input is power consumption; clearly a PC is of limited use without adequate or consistent power supply. Of course, after some threshold of connectivity or power level, ICT equipment and electricity might be substitutes. Finally, the productivity of a computer might be enhanced by telephone access. Telecommunications infrastructure might then be another complementary input.

Income is likely to be a key determinant of the consumer demand for computers. It has an effect on consumers' budget constraints, and it may also affect preferences for owning a computer, especially in the sense of "keeping up with the Joneses." Income may be especially important in the presence of liquidity constraints. Although some consumers may view computers as a worthwhile investment they may not be able to finance the purchase of one. Preferences for owning a computer are also likely to vary across individuals and may depend on exposure to and the perceived usefulness of owning a computer. ${ }^{12}$ This may be related to a person's education level, age, presence of children, and urban/rural location.

To estimate the demand function, one would need to be able to identify some exogenous variables in the supply equation. In the case of computers, one candidate variable is obvious the price of computers. On a global scale, this appears to be driven by exogenous forces (Moore's Law) at the level of analysis we are concerned with. An examination of the hedonic price indices calculated for ICT equipment in the US provides forceful evidence for large movements in the relative price of computing power. Indeed, Pohjola (2003) uses the US price of computing equipment as the price of computers in all economies he studies. Since this price index looks very similar to a (downward sloped) linear trend, it is not clear that in a structural setup, even one demand parameter could be identified (especially if there are deterministic time trends in the demand function). Consequently, we rely upon a reduced form estimation procedure, and assume that we cannot identify the underlying structural parameters.

Specifically, we estimate several reduced-form equations for computer penetration rates that include four main sets of independent variables. The first set includes conventional infrastructure variables, such as main telephone lines per capita, two measures of Internet access costs (monthly telephone subscription charges and the cost of a three minute call), and electricity

\footnotetext{
${ }^{12}$ A standard approach using microdata is to create a linear random utility model of the decision to purchase a computer (see Fairlie 2003 for example). The indirect utilities from the two choices are modelled as functions of measurable individual characteristics, such as race, sex, income, education, marital status, children, region and urbanicity.
} 
consumption. ${ }^{13}$ The second set includes demographic variables, such as shares of the population below 14 and above 65, and the share of the population in urban centers. The third set includes economic variables, such as income per capita and human capital (measured either as years of schooling or the illiteracy rate). The fourth category includes measures of institutional quality or policy, such as explicit measures of regulatory quality or trade openness. The latter can be construed as an economic characteristic, but it is often viewed as an indicator of how high trade barriers are. And, because trade barriers tend to be correlated with other domestic impediments to commerce, trade openness is often taken to be an indicator of a less regulated business environment.

We hypothesize that many of the same factors are likely to influence country-level Internet penetration rates. In particular, income, telecommunications infrastructure and costs, and regulatory quality may be especially important determinants of Internet use. We include the same set of regressors in the reduced-form equations for Internet penetration rates.

We first turn to the results for computer penetration rates from 1999-2001, which are reported in Table 2. In column (1), the results indicate that there are a number of clearly identifiable determinants of computer use. Unsurprisingly, income per capita comes in as a powerful determinant of PC use; each \$1000 increase in per capita income is associated with more than a one percentage point increase in the number of PCs per capita. ${ }^{14}$ Also not unexpectedly, human capital appears to be important. A one year increase in average schooling results in a one percentage point increase in PC penetration. Recent research on the determinants of computer ownership using microdata also finds strong relationships between computer ownership, and income and education. ${ }^{15}$ The positive relationship between per capita income and computer penetration rates may be partly due to relaxing the budget constraint, changing preferences, or liquidity constraints.

\footnotetext{
${ }^{13}$ Unfortunately, we do not have a measure of the percent of the population with access to electricity. Instead, we use per capita electricity consumption as a proxy.

${ }^{14}$ Scatter plots of computer penetration rates and income reveal an approximate linear relationship even at different income levels.

${ }^{15}$ Estimates from logit regressions using U.S. microdata indicate that an increase in family income of $\$ 50,000$ is associated with a 22 percentage point increase in the probability of having a home computer (or 0.44 percentage points per $\$ 1000$ family income, Fairlie 2003). Also, a college graduate has a 16.2 percentage point higher probability of having a home computer than an high school graduate (or 4.0 percentage points per year of school assuming 4 years of college). Note, however, that these estimates are not adjusted for the number of family members (i.e. per capita terms), the number of computers in a household, and non-home computers.
} 
One surprising result is the importance of telephone line density. A one percentage point increase in this variable is associated with a 0.4 percentage point increase in PC penetration. It is hard to interpret this result; it may be there are complementarities between computers and telephone lines. Telephone lines may be important for one of the most common uses of computers, accessing the Internet. Another explanation is that countries that have a well developed communication infrastructure are also likely to have other unobservable attributes that encourage PC use.

Demographic variables generally enter in with expected signs. A higher proportion of youth is associated with greater rate of PC use, while a lower rate will occur with a higher proportion of seniors, which is consistent with findings from microdata (U.S. Department of Commerce, 2002). On the other hand, the urban population enters with a significantly negative coefficient.

In the last set of variables, we find that the regulatory quality variable exhibits a high level of significance. ${ }^{16}$ This will be a recurring theme - an index of the economic policy environment shows up as a statistically important determinant (it will also turn out to be an economically important one as well, in the decompositions). Interestingly, unlike the outcome in many other empirical studies of growth, openness to international trade does not appear to be an important factor in PC use, after including an explicit measure of regulatory efficiency.

One puzzling result is the lack of a role for electricity consumption. There is essentially no relationship between per capita electricity use and PC penetration. This is surprising as access to electricity is essential for the use of personal computers. One possibility is that there is a threshold effect in the electricity-PC use relationship. Widespread availability of a reliable electricity supply is critical to making PC use economically efficient, and over the range where electrification is occurring, there may be a close link between consumption and use. Once nearly all households have access to electricity, the link between electricity consumption and PC use may break down. To investigate this possibility, we modify our electricity consumption variable so that values in excess of $6000 \mathrm{kWh}$ per capita are top coded at that value, thus allowing for a nonlinearity in this relationship. The level of $6000 \mathrm{kWh}$ was chosen because it represents a clear

\footnotetext{
${ }^{16}$ We also estimated a specification that includes a related measure which captures the degree to which agents have confidence in and abide by the rules of society (rule of law). This coefficient estimate is negative and statistically significant when added to the equation (perhaps due to its strong correlation with regulatory quality) and statistically insignificant when entered without regulatory quality.
} 
breakpoint in the bivariate relationship between electricity consumption and computer penetration rates. ${ }^{17}$

The results of estimating this specification are recorded in column (2). The coefficient estimates are very similar to those in column (1), with the exception of the electricity variable. The coefficient is now much larger in magnitude and is statistically significant. It implies that each $1000 \mathrm{kWh}$ increase in per capita electricity consumption is associated with a 1.8 percentage point increase in PC use, for countries with per capita electricity consumption below $6000 \mathrm{kWh}$. As noted above, it appears as though electricity consumption above this level has little effect on computer penetration rates. ${ }^{18}$

The use of our preferred measure of human capital, average years of schooling, constrains the sample size to 227. In column (3) we report the results estimating the regression, substituting the illiteracy rate for the years of schooling variable. The sample size increases to 273, and while the coefficient estimates on the other variables remain largely unchanged from column (2), the illiteracy rate has a statistically insignificant effect. The point estimate implies that a one percentage point increase in the illiteracy rate decreases the PC penetration rate by only 0.005 percentage points. These results are consistent with PC use requiring high levels of education and not simply basic literacy.

Another method of increasing the sample size is to drop the telephone cost variables which are not statistically significant in any of the specifications. We also drop electricity consumption which is missing for many countries. We obtain a slightly larger coefficient on income of 1.35 versus 0.96 in column (2). Otherwise, we are impressed by the relative robustness of the coefficient estimates.

We can substantially increase the sample size by additionally dropping the human capital variable altogether. At that point, the sample size increases to 417 . The sample now spans a wider set of countries, and gives greater weight to poorer countries, and those that have lower rates of PC use. The sample computer penetration rate drops to 10.17, as compared to the 14.14 in the baseline specification in column (1).

\footnotetext{
${ }^{17}$ Average per capita electricity consumption is roughly equal to $6000 \mathrm{kWh}$ in Germany, Denmark and the Netherlands.

${ }^{18}$ Estimates including a spline with a break point at 6000 for per capita electricity consumption confirm this. The slope above $6000 \mathrm{kWh}$ is very close to zero.
} 
Although the results are qualitatively similar using this larger sample, there are a few noteworthy changes. The coefficients on youth and aged dependency ratios, and the urban population ratio are smaller in magnitude. Youth dependency and urban population continue to be statistically significant determinants of PC use.

The coefficient on regulatory quality declines in absolute value, but remains large, positive and statistically significant. Consequently, we conclude that the institutional features of the policy regimes, such as the efficacy of regulatory quality or property rights, are important to PC use.

We also find that even using a sample size that is nearly twice as large as the one used in column (2), the coefficients on telephone line density and income change very little. The estimated effects of these two variables are very robust across the reported specifications.

\subsection{Internet Use}

We now take up the results for Internet penetration rates. To maximize comparability with the results for PC penetration rates, we retain the same basic set of regressors in our specification. In column (1), we find that several variables that were important, statistically, as determinants for PC penetration are also important factors in Internet penetration. These include electric power consumption, the youth dependency ratio, urban population (at the $10 \%$ level), per capita income and regulatory quality. Interestingly, the negative effect of regulations on Internet penetration (i.e. positive coefficient estimate on regulatory quality) is substantially larger than its effect on computer penetration. ${ }^{19}$ Another interesting finding is that the human capital variable does not show up as statistically significant, although it evidences the expected positive sign.

One surprising finding that runs counter to the conventional wisdom is that telephone density, and the Internet access pricing proxies - the monthly telephone subscription charge and the average cost of a three minute local call - do not enter in with statistical significance. These results may differ from those reported in Dasgupta, et al. (2001) and Liu and San (undated) because we examine a more recent period (1999-2001), and a different sample of countries. In particular, the effect that Mann, Eckert and Knight (2000) identify - that high per minute charges

\footnotetext{
${ }^{19}$ We find that rule of law has a statistically insignificant coefficient in specifications in which it is added as an additional regressor or entered without regulatory quality.
} 
may negatively affect Internet use more than high monthly subscription charge - may be swamped by other factors in our broader cross-country sample.

We find that the urban population ratio once again enters as a negative factor, which contrasts with the results in a number of other studies (Liu and San, undated). This finding suggests that after controlling for telephone density in a country, the Internet substitutes for the benefits accruing to operating in an urbanized environment. This result is consistent with the "Global Village Theory," as opposed to the "Urban Density Theory" (see Forman, Goldfarb, and Greenstein (2003) for a discussion of these theories, and the tests of the associated hypotheses using data from the US).

Another finding is that trade openness enters in with statistical significance (at the $10 \%$ level), although openness is associated with lower levels of Internet penetration. We discuss this finding more extensively below.

Most of these results are robust to modifications to the regression specification, including allowance for a threshold effect in electricity consumption (column (2)). In this particular specification, the coefficient on electricity consumption doubles in magnitude and becomes statistically significant, while the human capital variable becomes borderline significant. Substituting in a different proxy measure for human capital - the illiteracy rate - expands the sample size considerably (reported in column (3)), but does not yield a statistically significant effect for human capital, while the inferences regarding the other coefficients are generally unchanged, with the exception of the telephone density variable (which is now significant at the $10 \%$ level).

Dropping the access price proxies, along with the electricity consumption variable, but reverting to the years of schooling human capital variable, results in the estimates reported in column (4). With the exception of the income coefficient, which is larger, the coefficients imply smaller effects than those in column (2). Moreover, the human capital variable is not statistically significant in this specification.

Column (5) reports the results for a specification that omits the schooling, access price and electricity consumption variables. Omission of these variables once again increases the sample size considerably, to 470 observations. In this much larger sample that encompasses more developing countries, one finds that telephone density is now statistically significant. The coefficient increases from 0.12 to 0.15 with a large decline in the standard error. 
We also find statistically significant coefficients on the youth dependency ratio, per capita income, and regulatory quality. Interestingly, urbanization is no longer a statistically significant factor, suggesting that this is not a robust determinant of Internet use.

Trade openness is not statistically significant in its effects on Internet penetration. At the same time, regulatory quality has an attenuated impact; the coefficient estimate has declined from a value of 6.2 in the baseline specification to 2.7, along with a near halving of the standard errors. This pattern of results suggests to us that trade openness as defined in our data set is reflecting the effects of large closed economies like the US in the data set. The finding of a positive effect of trade openness in other studies may reflect the omission of a regulatory/policy variable such as the one we include in our regressions.

In sum, we identify electricity power consumption, youth dependency, income per capita and regulatory quality as robust determinants of Internet penetration. While a priori we believe telephone density and human capital to be important factors as well, the results do not bear out these beliefs in a broad sample.

\subsection{Robustness Checks}

To check the sensitivity of our results we estimated several additional regressions. We first estimated a model for computer penetration rates that includes country fixed effects. Although our panel only includes three years, the results are somewhat informative. We are concerned that there are unobserved country-level factors that may be correlated with some of the explanatory variables leading to biased coefficient estimates. Overall, the results are fairly similar to those from the random effects model. The coefficient estimates on income and telephone lines are slightly larger, and the coefficient estimate on regulatory quality is slightly smaller. The main exceptions are that the coefficient estimates on electric power consumption is much larger in the fixed effects model than the random effects model and the coefficient estimate on years of schooling is negative and implausibly large in absolute value. The coefficient estimate on years of schooling, which is now -10.0484 , may be the result of multicollinearity with the country fixed effects because this variable does not change much over time.

We also estimated a fixed effects model for Internet penetration rates. The coefficient estimates on the telecommunications variables remain statistically insignificant, and the coefficient on electrical power consumption is now much smaller and is no longer statistically 
significant. The coefficients on the population variables are much larger in the fixed effects regression and seem implausible. For example, the coefficient estimates, which are both statistically significant, imply that an increase of only 1 percentage point in the shares of the population that are ages 0-14 and 65 and over are associated with Internet penetration rates that are 3.84 and 5.61 percentage points higher, respectively. We also find large increases in the coefficients on GNI and years of schooling. The coefficient on years of schooling of 4.77 seems somewhat implausible. Finally, the coefficient on regulatory quality is somewhat smaller and the coefficient on trade is somewhat larger. Overall, the fixed effects results differ from the random effects model with a few cases in which the coefficients are implausibly large. Because of this concern, the relatively short time period of three years, and the loss of substantial crosssectional variation we do not focus on the fixed effects results below. Furthermore, the contribution estimates that we present in the following section preclude the use of fixed effects.

We also estimated models that weight countries by their population. Large countries, such as China and India, contribute substantially to identifying the coefficients in this model. Overall, the coefficient estimates in the computer penetration regressions are similar. The coefficients on telephone lines and electric power consumption are slightly smaller, and the coefficients on income, years of schooling and regulatory quality are slightly larger. Somewhat surprisingly, the weighted estimates are not overly sensitive to the exclusion of China and India.

For the Internet penetration rate regressions, we also find similar estimates after weighting by population. In particular, we find that the coefficients on electric power consumption, income, and regulatory quality are now slightly larger. The coefficient on years of schooling is slightly smaller and the coefficient on telephone lines remains statistically insignificant, but is now negative and small. These estimates are also not sensitive to excluding China and India.

We also estimated random effects models using an extended period: 1995 to 2001. In the computer regressions we find a larger coefficient on income, but smaller coefficients on years of schooling and regulatory quality. The coefficient on telephone lines is very similar. The coefficient on electric power consumption is now negative, but statistically insignificant. In the Internet regressions, the coefficients on income and telephone lines are larger, and the coefficients on years of schooling and regulatory quality are smaller. Surprisingly, the coefficient on electric power consumption is large, negative and statistically significant. We are 
concerned, however, that 1995 to 1998 includes a period of time when annual growth rates in computer and Internet penetration rates were increasing rapidly.

\section{Explanations for the Global Digital Divide}

\subsection{Methodology}

The regression analysis presented above reveals that factors such as income, human capital, telecommunications, electricity, and regulatory quality, contribute to the global digital divide. The analysis, however, does not identify the relative importance of these factors in contributing to the alarming differences in computer and Internet penetration rates across regions of the world. Another unanswered question is whether the explanations for low technology penetration rates differ across regions of the world.

To explore these issues further we borrow from a technique of decomposing inter-group differences in a dependent variable into those due to different observable characteristics across groups and those due to different "prices" of characteristics of groups (see Blinder 1973 and Oaxaca 1973). The technique has been widely used to decompose earnings gaps between whites and blacks or men and women using microdata. The Blinder-Oaxaca technique, however, can be used to decompose a gap between any two groups or even countries. In particular, the difference between an outcome, $Y$, for group $i$ and $j$ can be expressed as:

$$
\bar{Y}^{i}-\bar{Y}^{j}=\left(\bar{X}^{i}-\bar{X}^{j}\right) \hat{\beta}^{i}+\bar{X}^{j}\left(\hat{\beta}^{i}-\hat{\beta}^{j}\right),
$$

where $\bar{X}^{i}$ is a row vector of average values for the individual-level characteristics and $\hat{\beta}^{i}$ is a vector of coefficient estimates for group $i$. The first term in the decomposition represents the part of the gap that is due to group differences in average values of the independent variables, and the second term represents the part due to differences in the group processes determining the outcome, which is often referred to as the "unexplained" component. The first term can be further decomposed into the separate contributions from group differences in specific variables and is the focus of the following analysis.

The technique is commonly modified to use coefficients from a pooled sample of both

groups, $\hat{\beta}$, to weight the first expression in the decomposition (see Oaxaca and Ransom 1994 for example). We adopt this approach to calculate the decompositions. In particular, we use coefficient estimates from regressions that include most countries (reported in column 2 of tables 
2 and 3). We then denote the United States as the base group and calculate the decomposition for computer and Internet penetration rate gaps between the U.S. and each region. Thus, the first term in the decomposition that captures the explained variation in penetration rates between the United States and region $j$ is:

(6.2) $\left(\bar{X}^{\text {US }}-\bar{X}^{j}\right) \hat{\beta}$,

where $\hat{\beta}$ are the coefficients and $\bar{X}$ represents the three-year average of the independent variables included in the regressions. The technique allows us to quantify the separate contributions from U.S./Region $j$ differences in income, human capital, telephones, and other factors, to the gaps in computer and Internet penetration rates.

\subsection{Computer Use Contributions}

Table 4 reports the results for contributions to the regional/U.S. gaps in computer penetration rates. We report separate contribution estimates for regional differences in each of the explanatory variables. As indicated above, all regions have much lower computer penetration rates than the United States. The largest single factor contributing to these disparities in penetration rates is per capital income. For all regions, except Europe and Central Asia, differences in income explain approximately fifty percent of the gap in penetration rates. For Europe and Central Asia, income differences explain 39.4 percent of the gap.

The large contributions to the computer penetration rate gaps are not surprising considering the enormous disparities in income levels across regions of the world. The threeyear average per capita income (PPP adjusted) in the United States is $\$ 33,645$. In contrast, per capita income is only \$3,077 in Sub-Saharan Africa and \$2,473 in South Asia. The income gap is likely affecting computer penetration by way of the cost relative to income. A personal computer costing \$1500 represents half of a person's average annual income in Sub-Saharan Africa and more than half of their annual income in South Asia.

Although income is the largest contributing factor to the global digital divide it is clearly not the only factor. This result also holds for analyses within countries. For example, using U.S. microdata, Fairlie (2003) finds that income differences explain only 25 to 30 percent of the racial gap in computer ownership. Another factor that provides a substantial contribution to the computer penetration rate gaps is per capita telephone lines. This factor explains 35.0 to 40.7 percent of the regional gaps other than Europe and Central Asia. It explains 17.9 percent of the 
gap in this region. These results suggest that the assertion that the global digital divide is just a manifestation of a long-standing disparity in telecommunications access appears to be partly true (Dasgupta, et al. 2001). Interestingly, however, the effects of differences in telecommunications infrastructure are not due to costs, at least as measured by monthly subscription and per minute telephone charges. The contributions from these factors are essentially zero for all regions.

Regional differences in electric power consumption also contribute to the global digital divide. This factor explains 6.8 percent of the gap between Europe and Central Asia and the United States and from 15.1 to 17.8 percent of the gaps between other regions and the United States. Undoubtedly, countries in which relatively few people have access to reliable electricity provide limited opportunities for the use of personal computers. In this sense, it is possible that the use of per capita electric power consumption understates the true contribution of access to electricity to the regional gaps in computer penetration rates.

Interestingly, the United States and Europe and Central Asia have age distributions that are disadvantaged in terms of computer penetration rates relative to the rest of the world. The population in the United States is comprised of a lower percentage of children (ages 0-14) and a higher percentage of the elderly (ages 65 and over) than the rest of the world with the exception of Europe and Central Asia. The older population distribution in the United States combined with the negative relationship between age and computer penetration works to widen the technology gaps as evidenced by the negative contributions reported in table 4. In other words, if other regions of the world had an age distribution that was more similar to the United States the gaps in computer penetration rates would be even larger than they currently are. The one exception is for Europe and Central Asia. For this region the older age distribution explains part of the computer penetration rate gap.

The percent of the population living in urban areas also provides a negative contribution in the decompositions. Most regions have substantially more "rural" populations than the United States resulting in an advantaged geographical distribution in terms of computer use. The computer penetration rate gaps with the United States would be from 6.1 to 13.7 percent higher if these regions had a similar percentage of the population living in urban areas. The two exceptions are Europe and Central Asia, and Latin America and the Caribbean, which have comparably sized urban populations. 
Human capital disparities, as measured by years of schooling, are important in contributing to the global digital divide. Differences in education explain from 9.9 to 14.4 percent of the gaps in computer penetration rates. The average number of years of school range from 3.7 years in Sub-Saharan Africa to 8.3 years in Europe and Central Asia. In contrast, the average years of schooling in the United States is 12.1 years. Computers apparently require substantial levels of education for use, limiting demand in countries with relatively low levels of human capital. Hence, we confirm the findings of Caselli and Coleman (2001) and Pohjola (2003). This finding is significant because it indicates that even after controlling for differences in income, human capital disparities are important in creating a global digital divide. A parallel result can be found in research using U.S. microdata to explain the digital divide across racial groups. Demand for computers increases significantly with higher levels of education, resulting in large independent contributions from education to gaps in computer use (Fairlie, 2003).

Regional differences in regulatory quality appear to contribute greatly to the global digital divide. These differences explain roughly 10 percent of the gap in computer penetration rates for most regions. In the Middle East and North Africa, differences in regulatory quality explain nearly 15 percent of the gap in computer penetration. In Europe and Central Asia where regulatory quality is more similar to the United States this factor explains only 4.7 percent of the gap. Apparently, regulation has a negative net effect on technology adoption, partially explaining why many developing countries have low computer penetration rates, which is broadly consistent with the findings in Caselli and Coleman (2001). They find that their institutional variable - an index of property rights -- has a positive effect on computer investment in their largest sample. While in some of their smaller samples, including those that are less subject to measurement error, the effect is not always statistically significant, we find this effect to be robust across our specifications.

Finally, openness to trade, as measured by the percent of GDP represented by trade in goods, is not an important factor in contributing to the global digital divide. For none of the regions can this factor explain more than 1 percent of the gap in computer penetration rates. This outcome contrasts strongly with the Caselli and Coleman (2001) finding that computer investment, measured as computer imports, is highly dependent upon openness to imports from the OECD countries. Their interpretation of this finding is that this effect represents a knowledge spillover from importing manufactured goods. 


\subsection{Internet Decomposition Results}

Table 5 reports the results for contributions to regional/U.S. gaps in Internet penetration rates. The most important factor contributing to the gaps is income. Regional differences in gross national income per capita explain from 55.0 to 68.2 percent of the Internet penetration gaps. Although the contributions to the Internet gaps are larger than the contributions to the computer gaps in percentage terms, the actual contributions are similar. Surprisingly, access to telephones plays a smaller role in contributing to the regional gaps in Internet penetration rates. Telephone lines per capital explain from 7.8 to 16.1 percent of the gaps in Internet penetration rates. Furthermore, regional differences in monthly subscription or per call charges explain essentially none of the gap in Internet penetration rates. The global digital divide measured in Internet use appears to only partly be due to long-standing disparity in telecommunications access and is not related to differential telecommunications costs.

Access to electricity is also crucial to Internet use. Regional differences in electric power consumption explain 10.5 percent of the Internet penetration rate gap between Europe and Central Asia and the United States, and 20.9 to 25.0 percent of the Internet penetrations rates between other regions and the United States. The actual contributions are similar to those from the computer penetration rate decompositions.

Similar to the results presented above, the age distribution of the United States, and Europe and Central Asia limit the overall magnitude of the global digital divide. The effect, however, is entirely because of the relatively small percentage of children in these countries and not because of the relatively large percentage of the elderly compared to other regions of the world.

The relatively urban United States also lessens the global digital divide. The Internet penetration rate gaps would be larger for most regions as evidenced by the negative contribution estimates. However, this effect is fairly small. Interestingly, our estimated coefficient is opposite in sign from those obtained by Dasgupta et al. (2001) and APEC (2002). This suggests that the identified urban effect may be sensitive to sample or specification or both.

Regional differences in education levels appear to explain part of the gap, however, some caution is warranted in interpreting these results as they are based on a statistically insignificant 
coefficient estimate. The point estimate implies similar contributions as those for the computer penetration rate decompositions.

The most notable difference between the results for the Internet penetration rate gaps and those for the computer penetration rate gaps is the substantially larger magnitude of contributions from regional differences in regulatory quality. Differences in regulatory quality explain 11.7 percentage of the gap between Europe/Central Asia and the United States and 18.2 to 32.0 percentage of the gap between other regions and the United States. Again, these findings are consistent with those of Wallsten (2003) and suggest that regulation overall negatively affects Internet use.

\section{Conclusions}

In this paper we have uncovered several interesting findings - some expected and some unexpected. First, unsurprisingly, we confirm the importance of per capita income in explaining the gap in computer and Internet use. But rather than being the dominant factor, in certain instances the effect of other factors rival that of income. For instance, while 53.4 percent of the gap between the United States and Sub-Saharan African PC use is accounted for by income differentials, fully 40.7 percent of the gap can be attributed to the disparity in telecommunications infrastructure.

Second, we find that in a broad sample encompassing developed and developing countries, policy variables that have recently garnered attention - such as the pricing of telecommunications access - do not show up as statistically or economically important in explaining the Internet gap. This result should not be construed as implying that pricing policies are not important. Rather, it suggests that such issues are swamped by economic, demographic and institutional factors in samples with widely varying Internet penetration rates. Previous studies highlighting this issue had focused on relatively narrow sets of countries, such as the OECD countries.

Flowing from this conclusion is the third point: the quality of regulation is of great importance. Differences in regulatory quality generally account for large portions of the gaps in technology use. For instance, 32.0 percent of the US-Middle East/North Africa Internet gap is associated with the difference in regulatory quality. In other words, our estimates suggest that 
nearly one-third of the Internet penetration rate gap would be closed if countries in the Middle East and North Africa had similar regulatory quality as the United States.

We do not wish to imply that all our results are new or unexpected. Indeed, some are quite consistent with the extant literature on the causes of the digital divide. For instance, education does covary positively with the degree of PC and Internet use. But the degree to which the difference in Internet rates depends upon this variable is surprisingly small. For most of the regions, the effect of lower education is only about half the magnitude of the gap attributable to differences in regulatory efficiency. 


\section{Appendix \\ Variable Descriptions and Sources}

Key:

ITU: International Telecommunications Union, World Telecommunication Indicators Database. WDI: World Bank, World Development Indicators.

ES: World Bank, EdStats.

KKM: Kaufman, Kraay and Mastruzzi (2003).

Personal computers per 100 people: Estimates are derived from annual questionnaires supplemented by other sources. Source: ITU.

Internet users per 100 people: The number of Internet users is based on reported estimates, derivations based on reported Internet Access Provider (ISP) subscriber counts, or calculated by multiplying the number of hosts by an estimated multiplier. Source: ITU.

Main telephone lines per 100 people: Main telephone lines refer to telephone lines connecting a customer's equipment (e.g. telephone set, facsimile machine) to the Public Switched Telephone Network (PSTN) and which have a dedicated port on a telephone exchange. For most countries, main lines also include public payphones. Source: ITU.

Monthly telephone subscription charge: The monthly telephone subscription charge is the average of the residential and business subscription charges and is converted to international dollars using purchasing power parity rates provided by the World Bank. Monthly subscription refers to the recurring fixed charge for subscribing to the Public Switched Telephone Network. The charge covers the rental of the line but not the rental of the terminal (e.g., telephone set) where the terminal equipment market is liberalized. Source: ITU, WDI, and authors' calculations.

Cost of three minute local call: The cost of a three minute local call during peak rates is converted to international dollars using purchasing power parity rates provided by the World Bank. Source: ITU, WDI, and authors' calculations.

Electric power consumption (kwh per capita): Source: WDI.

Population ages 0-14 (\% of total): Source: WDI.

Population ages 65 and above (\% of total): Source: WDI.

Urban population (\% of total): Source: WDI.

Gross national income per capita: Gross national income is converted to international dollars using purchasing power parity rates provided by the World Bank. An international dollar has the same purchasing power over GNI as a U.S. dollar has in the United States. Source: WDI.

Trade in goods (\% of GDP): Sum of exports and imports, divided by GDP. Source: WDI. 
Years of schooling: Average years of schooling of adults. Source: ES.

Regulatory quality: The regulatory quality index focuses specifically on the policies, including measures of the incidence of market-unfriendly policies such as price controls or inadequate bank supervision, as well as perceptions of the burdens imposed by excessive regulation in areas such as foreign trade and business development. Source: KKM.

Rule of Law: A composite index that includes several indicators which measure the extent to which agents have confidence in and abide by the rules of society. These include perceptions of the incidence of crime, the effectiveness and predictability of the judiciary, and the enforceability of contracts. An Unobserved Component Model (UCM) is used to aggregate the various responses in the broad 6 clusters where the weights are proportional to the reliability of each source. The resulting estimates of governance have an expected value (across countries) of zero, and a standard deviation (across countries) of one. Source: KKM. 


\section{References}

Acemoglu, Daron, Simon Johnson, and James A. Robinson, 2001, "The Colonial origins of comparative development: An empirical investigation," American Economic Review 91(5): 1369-1401.

Autor, D., Lawrence Katz, and Alan Krueger, 1998, “Computing inequality: Have computers changed the labor market?” Quarterly Journal of Economics 113(4): 1169-1213.

Barro, Robert J., 1991, "Economic growth in a cross section of countries," Quarterly Journal of Economics, 106(2): 407-443.

Brynjolfsson, Erik and Loren Hitt, 2003, “Computing productivity: Firm-level evidence,” Review of Economics and Statistics 85(4): 793-808.

Casseli, Francesco, and Wilbur John Coleman II, 2001, "Cross-country technology diffusion: The case of computers,” NBER Working Paper No. 8130 (February).

Council of Economic Advisers, 2001, Economic Report of the President, 2001 (Washington, DC: U.S. GPO).

Dasgupta, Susmita, Somik Lall, and David Wheeler, 2001, "Policy reform, economic growth and the digital divide: An econometric analysis,” World Bank Working Paper No. 2567 (March).

Dedrick, Jason, Vijay Gurbaxani, and Kenneth Kraemer, 2003, "Information technology and economic performance: A critical review of the empirical evidence," ACM Computing Surveys 35(1) (March): 1-28.

Estache, Antonio, Marco Manacorda, Tommaso M. Valletti, 2002, "Telecommunication reforms, access regulation and internet adoption in Latin America,” World Bank Working Paper No. 2802 (March).

Fairlie, Robert W., 2002, "Race and the Digital Divide," Joint Center for Poverty Research Working Paper No. 307 (Northwestern University and University of Chicago).

Fink, Carsten and Charles Kenny, 2003, “W(h)ither the digital divide?” Info, The journal of policy, regulation and strategy for telecommunications 5(6).

Gordon, Robert, 2000, "Does the 'new economy' measure up to the great inventions of the past?” Journal of Economic Perspectives 14(4): 49-76.

Hall, Robert, and Chad I. Jones, 1999, "Why do some countries produce so much more output per worker than others?” Quarterly Journal of Economics 114 (1): 83-116.

Jorgenson, Dale, 2001, “Information technology and the U.S. economy,” American Economic Review 91(1): 1-32. 
Kaufmann, Daniel, Aart Kraay, and Massimo Mastruzzi, 2003, “Governance matters III: Governance indicators for 1996-2002,” mimeo (Washington, DC: World Bank, June).

Kawaguchi, Daiji, 2001, "Are computers at home a form of consumption or investment? A longitudinal analysis for Japan," mimeo (Michigan State University)

Kiiski, Sampsa, and Matti Pohjola, 2001, "Cross-country diffusion of the internet," WIDER Discussion Paper No. 2001/11 (Helsinki: World Institute for Development Economics Research).

Krueger, Alan B., 1993, "How computers have changed the wage structure: Evidence from micro data," The Quarterly Journal of Economics 107(1): 35-78.

Liu, Meng-chun and Gee San, undated, "Social conditions and the digital divide: Examining the role of internet diffusion,” mimeo (Taipei: Chung-Hua Institution for Economic Research).

Mann, Catherine, Sue E. Eckert, and Sarah Cleeland Knight, 2000, Global Electronic Commerce: A Policy Primer (Washington, DC: Institute for International Economics).

Norris, Pippa, 2001, Digital Divide: Civic Engagement, Information Poverty, and the Internet Worldwide (Cambridge: Cambridge University Press).

OECD, 2001, Understanding the Digital Divide (Paris: Organization for Economic Cooperation and Development).

Ono, Hiroshi, and Madeline Zavodny, 2003, "Gender differences in information technology usage: A U.S.-Japan comparison," mimeo (Stockholm School of Economics).

Oshikoya, T.W., and M. Nureldin Husseain, 1998, "Information technology and the challenge of economic development in Africa,” Economic Research Papers No. 36 (Abidjian, Côte d'Ivoire: African Development Bank).

Oyelaran-Oyeyinka, Banji and Kaushalesh Lal, 2003, “The internet diffusion in Sub-Saharan Africa: A cross-country analysis,” Institute for New Technologies Discussion Paper No. 2003-5 (Helsinki: UN University, July).

Pohjola, Matti, 2003, “The adoption and diffusion of ICT across countries: Patterns and determinants,” The New Economy Handbook (Academic Press).

Primrose, Jane. 2003. "2001 Census: Computer and Internet Use," Census Paper No. 03/03, Australian Bureau of Statistics.

Quibria, M. G., Shamsun N. Ahmed, Ted Tschang, and Mari-Len Reyes-Macasaquit, 2002, "Digital divide: Determinants and policies with special reference to Asia," Economics and Research Department Working Paper No. 27 (Manila: Asia Development Bank). 
Rodrik, Dani, Arvind Subramanian, and Francesco Trebbi, 2002, "Institutions rule: The primacy of institutions over geography and integration in economic development,” mimeo (Cambridge: Kennedy School of Government, Harvard University, October).

Sinai, Todd, and Joel Waldfogel, 2003, “Geography and the Internet: Is the Internet a substitute or a complement for cities?” NBER Working Paper No. 10028 (October).

Singh, Vik, 2004, "Factors associated with household internet use in Canada, 1998-2000," Agriculture and Rural Working Paper Series No. 66 (Ottawa: Statistics Canada).

Steinmuller, W. Edward, 2001, "ICTs and the possibilities of leapfrogging by developing countries," International Labour Review, 140(2): 193-210.

Temple, Jonathan, 2001, "Growth effects of education and social capital in the OECD countries,” OECD Economic Studies No. 33: 58-101.

U.S. Department of Commerce, 2000, Falling Through the Net: Toward Digital Inclusion (Washington, DC: U.S. GPO)

U.S. Department of Commerce, 2002, A Nation Online: How Americans are Expanding Their Use of the Internet (Washington, DC: U.S. GPO)

Wallsten, Scott, 2003, "Regulation and internet use in developing countries,” AEI-Brookings Joint Center for Regulatory Studies Related Publication 03-8 (Washington, DC: AEI and Brookings Institution, May).

World Bank, 2003, World Development Indicators (Washington, DC: World Bank). Available at: http://www.worldbank.org/data/wdi2002/index.htm 
Figure 1

World Computer and Internet Penetration Rates International Telecommunications Union (1990-2001)

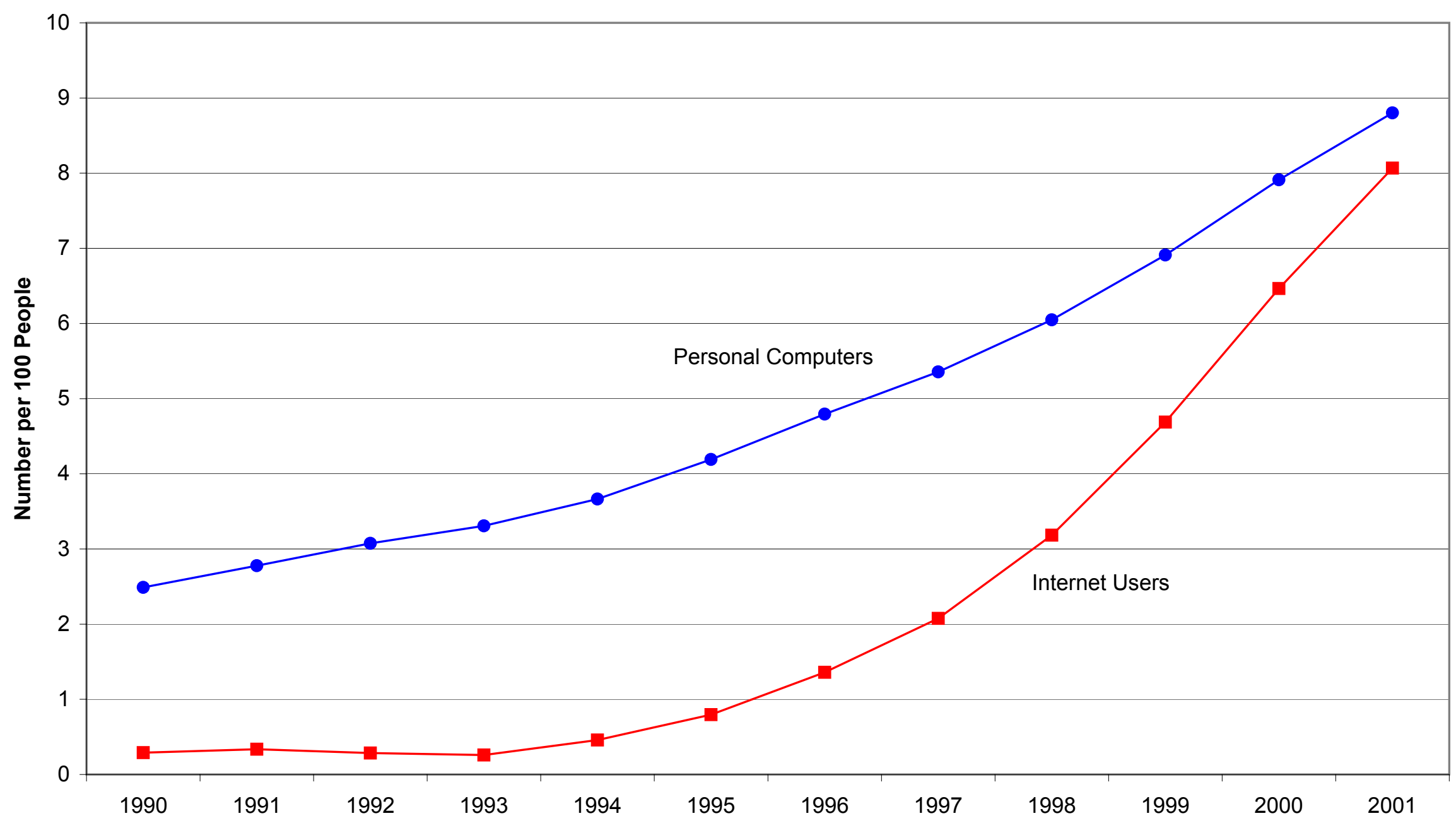


Figure 2

Regional Computer Penetration Rates

International Telecommuncations Union (2001)

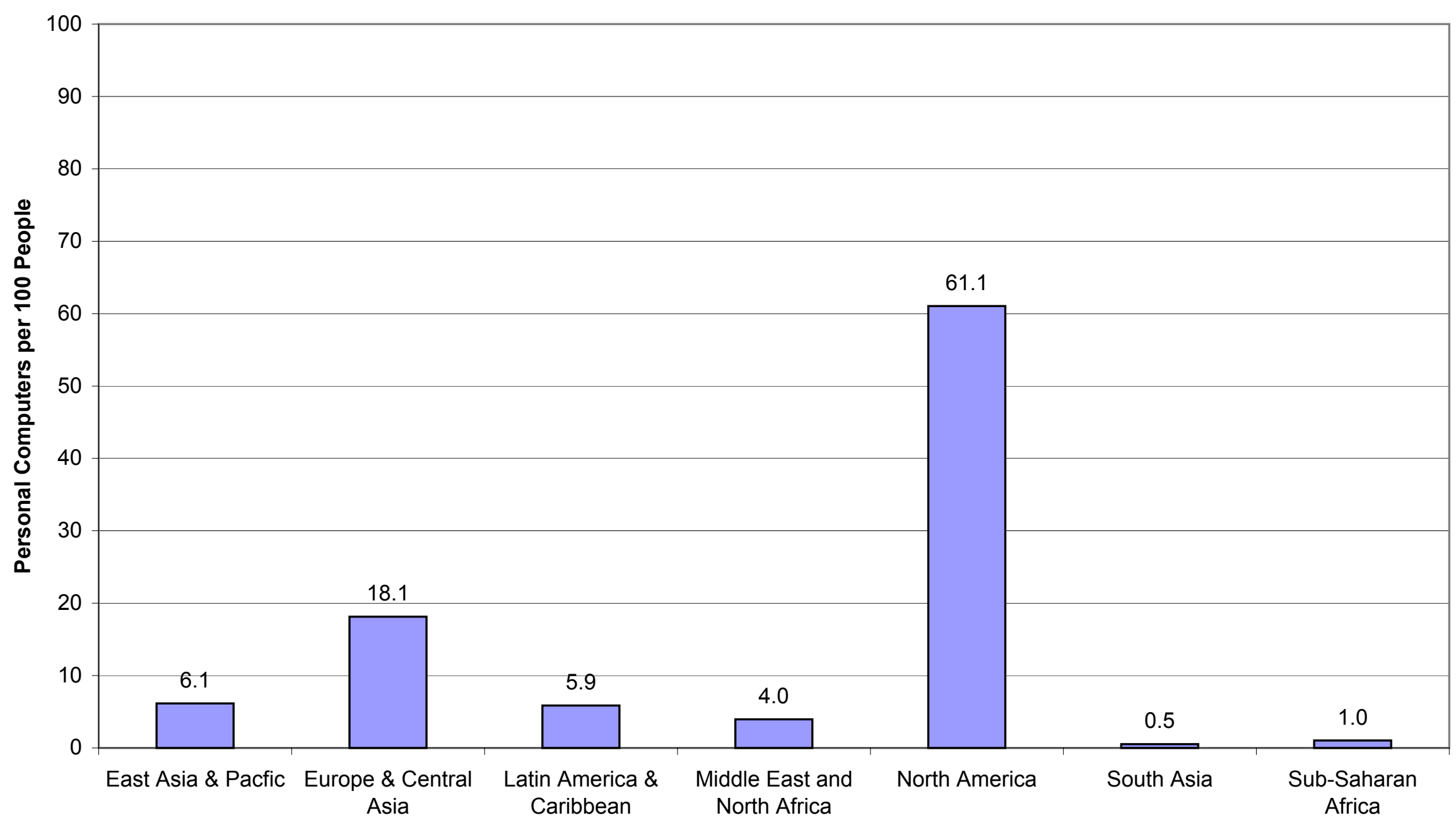


Figure 3

Regional Internet Penetration Rates

International Telecommuncations Union (2001)

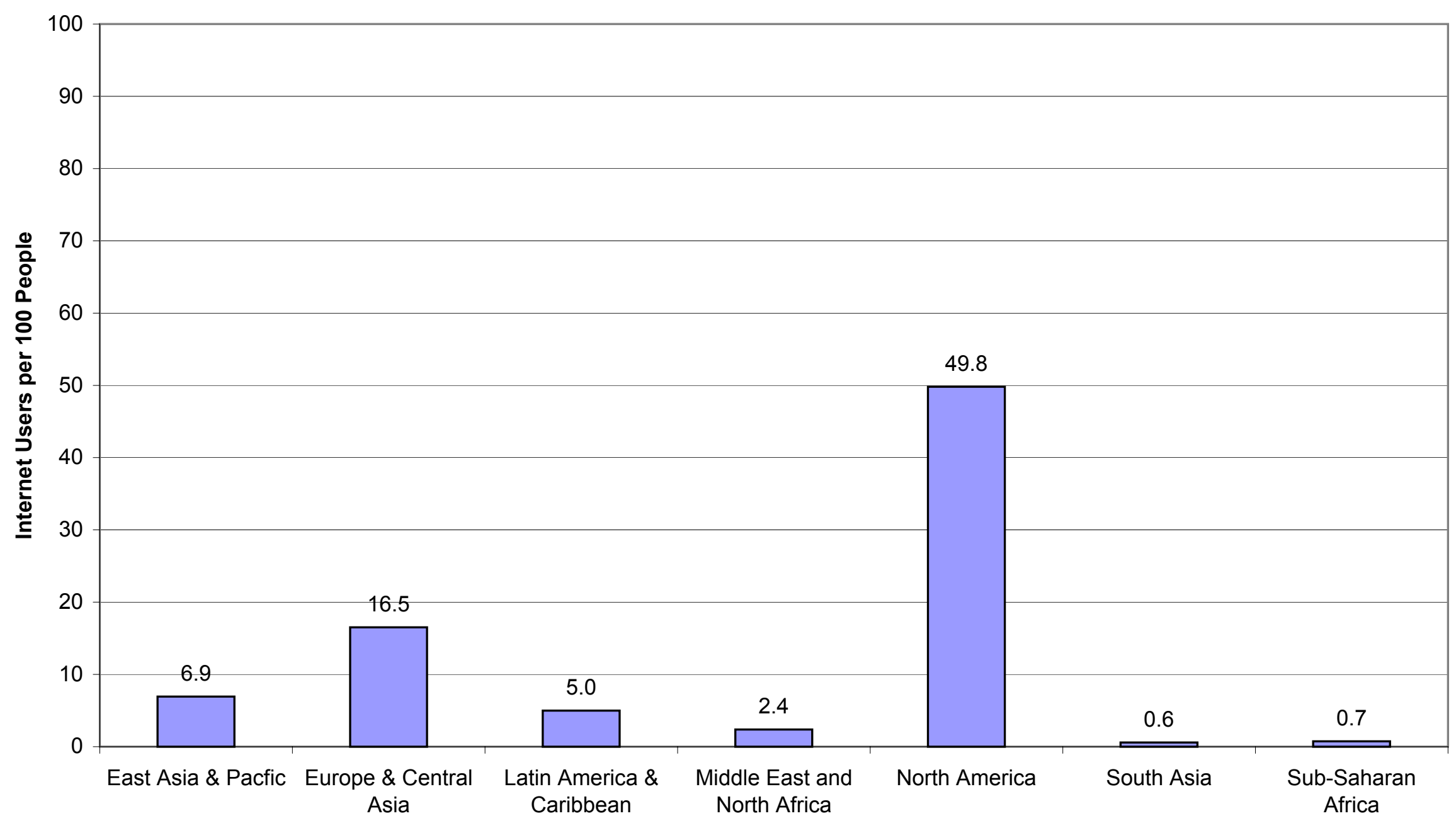


Table 1

Computer and Internet Penetration Rates for Highest, Lowest and Largest Countries International Telecommunications Union (2001)

\begin{tabular}{llrrr} 
Country & Region & $\begin{array}{c}\text { Computers } \\
\text { per }\end{array}$ & $\begin{array}{r}\text { Internet Users } \\
\text { per } 100\end{array}$ & \multicolumn{1}{r}{$\begin{array}{r}\text { Population } \\
\text { (000s) }\end{array}$} \\
\hline United States & North America & 62.50 & 50.15 & 284,797 \\
Sweden & Europe \& Central Asia & 56.12 & 51.63 & 8,910 \\
Denmark & Europe \& Central Asia & 54.15 & 42.95 & 5,355 \\
Switzerland & Europe \& Central Asia & 53.83 & 30.70 & 7,245 \\
Australia & East Asia \& Pacfic & 51.58 & 37.14 & 19,387 \\
Singapore & East Asia \& Pacfic & 50.83 & 41.15 & 4,131 \\
Norway & Europe \& Central Asia & 50.80 & 46.38 & 4,528 \\
Korea (Rep. of) & East Asia \& Pacfic & 48.08 & 52.11 & 46,790 \\
Canada & North America & 47.32 & 46.66 & 30,007 \\
Netherlands & Europe \& Central Asia & 42.84 & 49.05 & 16,105 \\
& & & & \\
Japan & East Asia \& Pacfic & 35.82 & 38.42 & 127,291 \\
Mexico & Latin America \& Caribbean & 6.87 & 3.62 & 100,368 \\
Brazil & Latin America \& Caribbean & 6.29 & 4.66 & 171,827 \\
Russia & Europe \& Central Asia & 4.97 & 2.93 & 146,760 \\
China & East Asia \& Pacfic & 1.90 & 2.57 & $1,312,710$ \\
Indonesia & East Asia \& Pacfic & 1.10 & 1.91 & 209,170 \\
Nigeria & Sub-Saharan Africa & 0.68 & 0.10 & 116,929 \\
India & South Asia & 0.58 & 0.68 & $1,027,015$ \\
Pakistan & South Asia & 0.41 & 0.34 & 144,971 \\
Bangladesh & South Asia & 0.19 & 0.14 & 131,175 \\
& & & & \\
Benin & Sub-Saharan Africa & 0.17 & 0.39 & 6,446 \\
Chad & Sub-Saharan Africa & 0.16 & 0.05 & 7,665 \\
Cambodia & East Asia \& Pacfic & 0.15 & 0.07 & 13,440 \\
Burkina Faso & Sub-Saharan Africa & 0.15 & 0.16 & 11,668 \\
Mali & Sub-Saharan Africa & 0.13 & 0.29 & 10,400 \\
Angola & Sub-Saharan Africa & 0.13 & 0.15 & 13,528 \\
Malawi & Sub-Saharan Africa & 0.13 & 0.19 & 10,386 \\
Ethiopia & Sub-Saharan Africa & 0.11 & 0.04 & 65,390 \\
Myanmar & East Asia \& Pacfic & 0.11 & 0.02 & 48,363 \\
Niger & Sub-Saharan Africa & 0.05 & 0.11 & 11,227 \\
\hline & & & &
\end{tabular}


Table 2

Computer Penetration Rate Regressions (1999-2001)

\begin{tabular}{|c|c|c|c|c|c|}
\hline Explanatory Variables & (1) & (2) & $\begin{array}{l}\text { pecification } \\
(3)\end{array}$ & (4) & $(5)$ \\
\hline $\begin{array}{l}\text { Main telephone lines per } \\
100 \text { people }\end{array}$ & $\begin{array}{c}0.3921 \\
(0.0785)\end{array}$ & $\begin{array}{c}0.3546 \\
(0.0784)\end{array}$ & $\begin{array}{c}0.3642 \\
(0.0681)\end{array}$ & $\begin{array}{c}0.3175 \\
(0.0693)\end{array}$ & $\begin{array}{c}0.3277 \\
(0.0504)\end{array}$ \\
\hline $\begin{array}{l}\text { Monthly telephone } \\
\text { subscription charge }\end{array}$ & $\begin{array}{l}-0.0125 \\
(0.0389)\end{array}$ & $\begin{array}{l}-0.0018 \\
(0.0385)\end{array}$ & $\begin{array}{c}0.0159 \\
(0.0347)\end{array}$ & & \\
\hline $\begin{array}{l}\text { Cost of three minute local } \\
\text { call }\end{array}$ & $\begin{array}{l}-3.5479 \\
(4.7353)\end{array}$ & $\begin{array}{l}-4.3132 \\
(4.6714)\end{array}$ & $\begin{array}{l}-1.2930 \\
(3.1691)\end{array}$ & & \\
\hline $\begin{array}{l}\text { Electric power consumption } \\
\quad \text { (kwh per capita) }\end{array}$ & $\begin{array}{c}0.0001 \\
(0.0002)\end{array}$ & $\begin{array}{c}0.0018 \\
(0.0007)\end{array}$ & $\begin{array}{c}0.0012 \\
(0.0006)\end{array}$ & & \\
\hline $\begin{array}{l}\text { Population ages } 0-14 \\
\quad(\% \text { of total) }\end{array}$ & $\begin{array}{c}0.4934 \\
(0.1515)\end{array}$ & $\begin{array}{l}0.6126 \\
(0.1550)\end{array}$ & $\begin{array}{c}0.2568 \\
(0.1451)\end{array}$ & $\begin{array}{c}0.4623 \\
(0.1289)\end{array}$ & $\begin{array}{c}0.2283 \\
(0.0915)\end{array}$ \\
\hline $\begin{array}{l}\text { Population ages } 65 \text { and } \\
\text { above (\% of total) }\end{array}$ & $\begin{array}{l}-0.7271 \\
(0.3187)\end{array}$ & $\begin{array}{l}-0.5871 \\
(0.3195)\end{array}$ & $\begin{array}{l}-0.4316 \\
(0.2833)\end{array}$ & $\begin{array}{l}-0.6376 \\
(0.2747)\end{array}$ & $\begin{array}{l}-0.2769 \\
(0.2125)\end{array}$ \\
\hline Urban population ( $\%$ of total) & $\begin{array}{l}-0.1313 \\
(0.0388)\end{array}$ & $\begin{array}{l}-0.1563 \\
(0.0397)\end{array}$ & $\begin{array}{l}-0.1303 \\
(0.0370)\end{array}$ & $\begin{array}{l}-0.1011 \\
(0.0337)\end{array}$ & $\begin{array}{l}-0.0675 \\
(0.0232)\end{array}$ \\
\hline $\begin{array}{l}\text { Gross national income per } \\
\quad \text { capita }(000 \mathrm{~s})\end{array}$ & $\begin{array}{c}1.1669 \\
(0.1628)\end{array}$ & $\begin{array}{l}0.9636 \\
(0.1779)\end{array}$ & $\begin{array}{c}0.9220 \\
(0.1586)\end{array}$ & $\begin{array}{l}1.3503 \\
(0.1405)\end{array}$ & $\begin{array}{c}1.0670 \\
(0.0955)\end{array}$ \\
\hline Years of schooling & $\begin{array}{c}0.9786 \\
(0.4453)\end{array}$ & $\begin{array}{c}0.9541 \\
(0.4369)\end{array}$ & & $\begin{array}{l}0.7824 \\
(0.3799)\end{array}$ & \\
\hline Regulatory quality & $\begin{array}{l}3.6088 \\
(0.7029)\end{array}$ & $\begin{array}{c}3.8128 \\
(0.6963)\end{array}$ & $\begin{array}{c}2.6443 \\
(0.5980)\end{array}$ & $\begin{array}{c}3.0540 \\
(0.6296)\end{array}$ & $\begin{array}{c}1.9156 \\
(0.4473)\end{array}$ \\
\hline Trade in goods ( $\%$ of GDP) & $\begin{array}{l}-0.0082 \\
(0.0085)\end{array}$ & $\begin{array}{l}-0.0100 \\
(0.0083)\end{array}$ & $\begin{array}{l}-0.0072 \\
(0.0072)\end{array}$ & $\begin{array}{l}-0.0061 \\
(0.0076)\end{array}$ & $\begin{array}{c}0.0006 \\
(0.0059)\end{array}$ \\
\hline Illiteracy rate & & & $\begin{array}{c}-0.0054 \\
(0.0473)\end{array}$ & & \\
\hline Average Computer Pen. Rate & 14.14 & 14.14 & 12.67 & 12.73 & 10.17 \\
\hline Sample Size & 227 & 227 & 273 & 276 & 417 \\
\hline
\end{tabular}

Notes: (1) The dependent variable is the number of personal computers per 100 people. (2) Estimates account for country-level random effects. (3) Standard errors are reported below coefficient estimates. (4) Specifications 2 and 3 include censored values for electric power consumption above $6000 \mathrm{kwh}$. 
Table 3

Internet Penetration Rate Regressions (1999-2001)

\begin{tabular}{|c|c|c|c|c|c|}
\hline Explanatory Variables & (1) & $(2)$ & $\begin{array}{l}\text { pecification } \\
(3)\end{array}$ & (4) & (5) \\
\hline $\begin{array}{l}\text { Main telephone lines per } \\
100 \text { people }\end{array}$ & $\begin{array}{c}0.1211 \\
(0.1018)\end{array}$ & $\begin{array}{c}0.1075 \\
(0.1069)\end{array}$ & $\begin{array}{c}0.1663 \\
(0.0897)\end{array}$ & $\begin{array}{c}0.1355 \\
(0.0896)\end{array}$ & $\begin{array}{c}0.1470 \\
(0.0626)\end{array}$ \\
\hline $\begin{array}{l}\text { Monthly telephone } \\
\text { subscription charge }\end{array}$ & $\begin{array}{l}-0.0367 \\
(0.0442)\end{array}$ & $\begin{array}{l}-0.0296 \\
(0.0470)\end{array}$ & $\begin{array}{c}0.0013 \\
(0.0419)\end{array}$ & & \\
\hline $\begin{array}{l}\text { Cost of three minute local } \\
\text { call }\end{array}$ & $\begin{array}{l}-1.2782 \\
(6.4403)\end{array}$ & $\begin{array}{l}-1.0440 \\
(6.6763)\end{array}$ & $\begin{array}{c}1.8345 \\
(4.5701)\end{array}$ & & \\
\hline $\begin{array}{l}\text { Electric power consumption } \\
\quad \text { (kwh per capita) }\end{array}$ & $\begin{array}{c}0.0008 \\
(0.0002)\end{array}$ & $\begin{array}{c}0.0019 \\
(0.0009)\end{array}$ & $\begin{array}{c}0.0018 \\
(0.0008)\end{array}$ & & \\
\hline $\begin{array}{l}\text { Population ages } 0-14 \\
\text { ( } \% \text { of total) }\end{array}$ & $\begin{array}{c}0.5125 \\
(0.1782)\end{array}$ & $\begin{array}{c}0.7509 \\
(0.1978)\end{array}$ & $\begin{array}{c}0.4600 \\
(0.1716)\end{array}$ & $\begin{array}{l}0.5074 \\
(0.1507)\end{array}$ & $\begin{array}{c}0.3126 \\
(0.1056)\end{array}$ \\
\hline $\begin{array}{l}\text { Population ages } 65 \text { and } \\
\text { above ( } \% \text { of total) }\end{array}$ & $\begin{array}{c}0.0986 \\
(0.3833)\end{array}$ & $\begin{array}{c}0.1167 \\
(0.4135)\end{array}$ & $\begin{array}{c}0.3886 \\
(0.3465)\end{array}$ & $\begin{array}{l}-0.1068 \\
(0.3293)\end{array}$ & $\begin{array}{c}0.3864 \\
(0.2481)\end{array}$ \\
\hline Urban population ( $\%$ of total) & $\begin{array}{l}-0.0754 \\
(0.0440)\end{array}$ & $\begin{array}{l}-0.1127 \\
(0.0492)\end{array}$ & $\begin{array}{l}-0.0931 \\
(0.0419)\end{array}$ & $\begin{array}{l}-0.0720 \\
(0.0381)\end{array}$ & $\begin{array}{l}-0.0293 \\
(0.0264)\end{array}$ \\
\hline $\begin{array}{l}\text { Gross national income per } \\
\text { capita (000s) }\end{array}$ & $\begin{array}{c}0.8383 \\
(0.2074)\end{array}$ & $\begin{array}{c}0.9379 \\
(0.2485)\end{array}$ & $\begin{array}{c}0.6996 \\
(0.2134)\end{array}$ & $\begin{array}{l}1.3507 \\
(0.1823)\end{array}$ & $\begin{array}{c}0.9493 \\
(0.1210)\end{array}$ \\
\hline Years of schooling & $\begin{array}{c}0.6799 \\
(0.4963)\end{array}$ & $\begin{array}{l}0.9100 \\
(0.5326)\end{array}$ & & $\begin{array}{c}0.5402 \\
(0.4255)\end{array}$ & \\
\hline Regulatory quality & $\begin{array}{c}6.2244 \\
(1.0072)\end{array}$ & $\begin{array}{c}6.5585 \\
(1.0377)\end{array}$ & $\begin{array}{c}4.3089 \\
(0.7991)\end{array}$ & $\begin{array}{c}4.4878 \\
(0.8630)\end{array}$ & $\begin{array}{c}2.6861 \\
(0.5835)\end{array}$ \\
\hline Trade in goods ( $\%$ of GDP) & $\begin{array}{c}-0.0233 \\
(0.0124)\end{array}$ & $\begin{array}{c}-0.0335 \\
(0.0126)\end{array}$ & $\begin{array}{c}-0.0212 \\
(0.0107)\end{array}$ & $\begin{array}{l}-0.0257 \\
(0.0107)\end{array}$ & $\begin{array}{c}-0.0041 \\
(0.0085)\end{array}$ \\
\hline Illiteracy rate & & & $\begin{array}{l}-0.0259 \\
(0.0523)\end{array}$ & & \\
\hline $\begin{array}{l}\text { Average Computer Pen. Rate } \\
\text { Sample Size }\end{array}$ & $\begin{array}{c}12.38 \\
228\end{array}$ & $\begin{array}{c}12.38 \\
228\end{array}$ & $\begin{array}{c}10.71 \\
285\end{array}$ & $\begin{array}{c}10.43 \\
297\end{array}$ & $\begin{array}{l}7.74 \\
470\end{array}$ \\
\hline
\end{tabular}

Notes: (1) The dependent variable is the number of personal computers per 100 people. (2) Estimates account for country-level random effects. (3) Standard errors are reported below coefficient estimates. (4) Specifications 2 and 3 include censored values for electric power consumption above $6000 \mathrm{kwh}$. 
Table 4

Decomposition of Computer Penetration Rate for 1999-2001

\begin{tabular}{|c|c|c|c|c|c|c|}
\hline & $\begin{array}{c}\text { East Asia } \\
\text { and Pacific }\end{array}$ & $\begin{array}{l}\text { Europe and } \\
\text { Central Asia }\end{array}$ & $\begin{array}{c}\text { Latin } \\
\text { America and } \\
\text { Caribbean }\end{array}$ & $\begin{array}{c}\text { Middle East } \\
\text { and North } \\
\text { Africa }\end{array}$ & South Asia & $\begin{array}{c}\text { Sub-Saharan } \\
\text { Africa } \\
\end{array}$ \\
\hline Computer Penetration Rate & 5.39 & 23.40 & 5.00 & 3.57 & 0.43 & 1.68 \\
\hline U.S. Rate & 56.86 & 56.86 & 56.86 & 56.86 & 56.86 & 56.86 \\
\hline Gap & 51.47 & 33.46 & 51.86 & 53.29 & 56.43 & 55.18 \\
\hline \multicolumn{7}{|l|}{ Contribution from differences in: } \\
\hline Main telephone lines per & 18.27 & 5.98 & 18.13 & 19.41 & 22.55 & 22.45 \\
\hline 100 people & $35.5 \%$ & $17.9 \%$ & $35.0 \%$ & $36.4 \%$ & $40.0 \%$ & $40.7 \%$ \\
\hline Monthly telephone & -0.03 & -0.03 & -0.02 & -0.05 & 0.00 & -0.03 \\
\hline subscription charge & $0.0 \%$ & $-0.1 \%$ & $0.0 \%$ & $-0.1 \%$ & $0.0 \%$ & $0.0 \%$ \\
\hline Cost of three minute local & 0.30 & 0.66 & 0.58 & 0.17 & 0.46 & 0.96 \\
\hline call & $0.6 \%$ & $2.0 \%$ & $1.1 \%$ & $0.3 \%$ & $0.8 \%$ & $1.7 \%$ \\
\hline Electric power consumption & 8.22 & 2.28 & 7.81 & 8.41 & 10.07 & 9.10 \\
\hline (kwh per capita) & $16.0 \%$ & $6.8 \%$ & $15.1 \%$ & $15.8 \%$ & $17.8 \%$ & $16.5 \%$ \\
\hline Population ages $0-14$ & -2.58 & 1.70 & -6.37 & -8.41 & -8.24 & -12.23 \\
\hline (\% of total) & $-5.0 \%$ & $5.1 \%$ & $-12.3 \%$ & $-15.8 \%$ & $-14.6 \%$ & $-22.2 \%$ \\
\hline Population ages 65 and & -3.15 & 1.13 & -4.26 & -4.88 & -4.70 & -5.41 \\
\hline above ( $\%$ of total) & $-6.1 \%$ & $3.4 \%$ & $-8.2 \%$ & $-9.2 \%$ & $-8.3 \%$ & $-9.8 \%$ \\
\hline \multirow{2}{*}{ Urban population (\% of total) } & -5.48 & -0.21 & -0.10 & -3.24 & -7.75 & -5.73 \\
\hline & $-10.7 \%$ & $-0.6 \%$ & $-0.2 \%$ & $-6.1 \%$ & $-13.7 \%$ & $-10.4 \%$ \\
\hline \multirow{2}{*}{$\begin{array}{l}\text { Gross national income per } \\
\text { capita }(000 \mathrm{~s})\end{array}$} & 26.86 & 13.20 & 25.69 & 27.40 & 30.04 & 29.45 \\
\hline & $52.2 \%$ & $39.4 \%$ & $49.5 \%$ & $51.4 \%$ & $53.2 \%$ & $53.4 \%$ \\
\hline \multirow[t]{2}{*}{ Years of schooling } & 5.12 & 3.53 & 5.66 & 6.19 & 7.04 & 7.92 \\
\hline & $9.9 \%$ & $10.6 \%$ & $10.9 \%$ & $11.6 \%$ & $12.5 \%$ & $14.4 \%$ \\
\hline \multirow[t]{2}{*}{ Regulatory quality } & 5.95 & 1.59 & 4.25 & 7.88 & 6.49 & 6.42 \\
\hline & $11.6 \%$ & $4.7 \%$ & $8.2 \%$ & $14.8 \%$ & $11.5 \%$ & $11.6 \%$ \\
\hline \multirow[t]{2}{*}{ Trade in goods ( $\%$ of GDP) } & 0.25 & 0.34 & 0.15 & 0.19 & 0.04 & 0.22 \\
\hline & $0.5 \%$ & $1.0 \%$ & $0.3 \%$ & $0.4 \%$ & $0.1 \%$ & $0.4 \%$ \\
\hline
\end{tabular}

Note: The coefficient estimates used in these calculations are from Specification 2 of Table 2. See text for more details on calculations. 
Table 5

Decomposition of Internet Penetration Rate for 1999-2001

\begin{tabular}{|c|c|c|c|c|c|c|}
\hline & $\begin{array}{c}\text { East Asia } \\
\text { and Pacific }\end{array}$ & $\begin{array}{l}\text { Europe and } \\
\text { Central Asia }\end{array}$ & $\begin{array}{c}\text { Latin } \\
\text { America and } \\
\text { Caribbean }\end{array}$ & $\begin{array}{c}\text { Middle East } \\
\text { and North } \\
\text { Africa }\end{array}$ & South Asia & $\begin{array}{c}\text { Sub-Saharan } \\
\text { Africa }\end{array}$ \\
\hline Internet Penetration Rate & 5.34 & 20.34 & 3.59 & 1.31 & 0.43 & 1.31 \\
\hline U.S. Rate & 43.69 & 43.69 & 43.69 & 43.69 & 43.69 & 43.69 \\
\hline Gap & 38.35 & 23.35 & 40.10 & 42.38 & 43.26 & 42.38 \\
\hline \multicolumn{7}{|l|}{ Contribution from differences in: } \\
\hline Main telephone lines per & 5.54 & 1.81 & 5.50 & 5.89 & 6.84 & 6.81 \\
\hline 100 people & $14.4 \%$ & $7.8 \%$ & $13.7 \%$ & $13.9 \%$ & $15.8 \%$ & $16.1 \%$ \\
\hline Monthly telephone & -0.41 & -0.50 & -0.26 & -0.79 & -0.05 & -0.41 \\
\hline subscription charge & $-1.1 \%$ & $-2.1 \%$ & $-0.6 \%$ & $-1.9 \%$ & $-0.1 \%$ & $-1.0 \%$ \\
\hline Cost of three minute local & 0.07 & 0.16 & 0.14 & 0.04 & 0.11 & 0.23 \\
\hline call & $0.2 \%$ & $0.7 \%$ & $0.3 \%$ & $0.1 \%$ & $0.3 \%$ & $0.5 \%$ \\
\hline Electric power consumption & 8.82 & 2.45 & 8.40 & 9.04 & 10.82 & 9.78 \\
\hline (kwh per capita) & $23.0 \%$ & $10.5 \%$ & $20.9 \%$ & $21.3 \%$ & $25.0 \%$ & $23.1 \%$ \\
\hline Population ages $0-14$ & -3.16 & 2.09 & -7.81 & -10.31 & -10.10 & -15.00 \\
\hline (\% of total) & $-8.3 \%$ & $8.9 \%$ & $-19.5 \%$ & $-24.3 \%$ & $-23.4 \%$ & $-35.4 \%$ \\
\hline Population ages 65 and & 0.63 & -0.22 & 0.85 & 0.97 & 0.94 & 1.07 \\
\hline above (\% of total) & $1.6 \%$ & $-1.0 \%$ & $2.1 \%$ & $2.3 \%$ & $2.2 \%$ & $2.5 \%$ \\
\hline \multirow[t]{2}{*}{ Urban population (\% of total) } & -3.95 & -0.15 & -0.08 & -2.34 & -5.59 & -4.13 \\
\hline & $-10.3 \%$ & $-0.7 \%$ & $-0.2 \%$ & $-5.5 \%$ & $-12.9 \%$ & $-9.7 \%$ \\
\hline \multirow{2}{*}{$\begin{array}{l}\text { Gross national income per } \\
\text { capita }(000 \mathrm{~s})\end{array}$} & 26.15 & 12.85 & 25.01 & 26.67 & 29.24 & 28.67 \\
\hline & $68.2 \%$ & $55.0 \%$ & $62.4 \%$ & $62.9 \%$ & $67.6 \%$ & $67.7 \%$ \\
\hline \multirow[t]{2}{*}{ Years of schooling } & 4.88 & 3.37 & 5.41 & 5.90 & 6.71 & 7.56 \\
\hline & $12.7 \%$ & $14.4 \%$ & $13.5 \%$ & $13.9 \%$ & $15.5 \%$ & $17.8 \%$ \\
\hline \multirow[t]{2}{*}{ Regulatory quality } & 10.23 & 2.73 & 7.32 & 13.55 & 11.17 & 11.04 \\
\hline & $26.7 \%$ & $11.7 \%$ & $18.2 \%$ & $32.0 \%$ & $25.8 \%$ & $26.1 \%$ \\
\hline \multirow[t]{2}{*}{ Trade in goods ( $\%$ of GDP) } & 0.84 & 1.15 & 0.51 & 0.64 & 0.12 & 0.74 \\
\hline & $2.2 \%$ & $4.9 \%$ & $1.3 \%$ & $1.5 \%$ & $0.3 \%$ & $1.8 \%$ \\
\hline
\end{tabular}

Note: The coefficient estimates used in these calculations are from Specification 2 of Table 3. See text for more details on calculations. 